\title{
Thoughts on the Experience of God in the Theology of Karl Rahner: Gifts and Implications
}

\author{
Mary Steinmetz* \\ Boston College School of Theology \& Ministry
}

This paper explores the concept of encounter with God in the writings of Karl Rahner and its relevance for academic study and spiritual practice today. In the first half of the paper, the author explores how Rahner addresses the experience of Ultimate Mystery in a variety of ways, by offering insights from his academic writings, prayers, and short articles. In the second half, particular attention is given to the possible applications of his understanding of the experience of God for Christians today, feminist theology, addressing the academic theology/spirituality split, and re-imagining the deep longing for tangible experience in the lives of many Christians.

\footnotetext{
* Mary Steinmetz will graduate in May with a M.T.S. degree from the School of Theology and Ministry at Boston College. She has a M.A. in Holistic Spirituality from Chestnut Hill College, where she was also employed in various positions, most recently as Director of Psy.D. Admissions. Mary is interested in the intersection between spirituality and theology, and has offered parish retreats on various topics.
} 


\section{Introduction}

Karl Rahner's theology does much to de-mythologize mysticism. ${ }^{1}$ He approaches the experience of God as an ordinary occurrence, and this sense of normality is related to his understanding of the human person as one who is ultimately oriented toward transcendence. This makes his work particularly relevant to spirituality because he presents the divine as accessible while maintaining the incomprehensibility of Holy Mystery. ${ }^{2}$ He avoids the trap of presenting God as a two-dimensional "buddy" by insisting on the utter transcendence of Mystery. At the same time, he believes that every human being has experienced this Mystery directly and needs only to be taught to recognize the encounter with the transcendent. His focus is on the ordinary experience of God, and not the extremes of many of the mystics, though he does not deny these experiences or their value for the Church.

This paper will examine the various ways that Rahner presents the experience of God and then explore the opportunities this presents for spirituality today. Since he saw himself as a spiritual theologian and his theology is found in prayers, interviews, and spiritual writing, as well as more academic pieces, this task will involve a review of various types of sources. This material will then be analyzed for potential contributions to spirituality, spiritual practice, and current, particularly feminist, understandings of the human/divine relationship.

\section{The Human Person and the Experience of God}

"The devout Christian of the future will either be a 'mystic,' one who has experienced 'something,' or he will cease to be anything at all." ${ }^{33}$ This is an often-cited Rahner quote, but what exactly does it mean? Rahner sees the human person as being consciously or subconsciously aware of God, not necessarily in an obvious way but rather as the horizon of

\footnotetext{
${ }^{1}$ Following Rahner's lead, I will not try to define mysticism. As he says: "We do after all possess a vague empirical concept of Christian mysticism: the religious experiences of the Saints, all that they experienced of closeness to God, of higher impulses, of visions, inspirations, of the consciousness of being under the special and personal guidance of the Holy Spirit, of ecstasies, etc., all this is comprised in our understanding of the word mysticism, without our having to stop here to ask what exactly it is that is of ultimate importance in all this, and in what more precisely this proper element consists," "The Ignatian Mysticism of Joy in the World," in Theological Investigations III, trans. Karl H. and Boniface Kruger OFM (Baltimore, MD: Helicon Press, 1967; originally published by Einsiedeln, Benziger in 1956 as Zur Theologie des geistlichen Lebens), 279-280.

${ }^{2}$ Rahner uses a wealth of terms to speak of God. The most common utilize the word "mystery," which Rahner uses to emphasize the idea that God is always beyond our ability to conceptualize or understand. To give the reader a sense of the richness of Rahner's language, different terms will be used throughout this paper. When he means to use a Trinitarian schema, Rahner uses the traditional "Father," "Son," and Spirit. Other than this traditional usage, Rahner's terminology is not gender-specific.

${ }^{3}$ Karl Rahner, "Christian Living Formerly and Today," in Theological Investigations VII, trans. David Bourke (New York: Herder and Herder, 1971), 15 as quoted in Harvey D. Egan, Soundings in the Christian Mystical Tradition (Collegeville, MN: Liturgical Press, 2010), 338. Here, as elsewhere, Rahner uses the masculine pronoun when speaking of the human person or of God. While the author of this article objects to such usage, she would like to acknowledge her belief that this is a result of the time in which Rahner wrote and not any desire to denigrate women or to assign "maleness" to God. In respect to Rahner, his words will not be edited to make them more palatable to those offended by sexist language, but the author hopes that the reader will overlook the unintentional sexism.
} 
consciousness. This means that he begins with a definition of the human person that makes relation to God a defining principle. It is not surprising that the experience of God then becomes an important part of his theology. In doing this, he opens the realm of the sacred to include every aspect of human life. Since Rahner's theological anthropology is foundational for understanding his approach to the experience of God, it is important to begin with a closer look at this facet of his theology.

For Rahner, the human person is understood as one who is created for the selfcommunication of God. This orientation toward Ultimate Mystery is the foundational characteristic of being human. Starting from this perspective, the experience of God is not something unusual; rather, to be human is to be open to the possibility of God's selfcommunication. This radical orientation to mystery at the root of humanity is what is meant by Rahner's phrase "supernatural existential." This openness to Mystery as the horizon that is always ever greater is the possibility for the receipt of grace, which is defined as the communication of God's own self. Thus, the potential to respond to God's offer of Godself, or obediential potential (or potency), is a result of what the human being is created to be. "To Rahner, God's self-offer as holy mystery, revelation, and love actually constitutes human identity. To be human in its most radical sense means to be the addressee of God's offer of self.",5

This understanding of the human person leads Rahner to insist that everyone has had experiences of God, whether they are unrecognized (unthematic) or more explicit (thematic). The unthematic experiences that he identifies as encounters with Mystery are deeply human:

Have we ever kept quiet, even though we wanted to defend ourselves when we had been unfairly treated? Have we ever forgiven someone even though we got no thanks for it and our silent forgiveness was taken for granted? ... Have we ever sacrificed something without receiving any thanks or recognition for it, and even without a feeling of inner satisfaction? Have we ever been absolutely lonely? Have we ever decided on some course of action purely by the innermost judgment of our conscience, deep down where one can no longer tell or explain it to anyone, where one is quite alone and knows that one is taking a decision which no one else can take in one's place and for which one will have to answer for all eternity? ...For the experience meant here is the experience of eternity. ${ }^{6}$

\footnotetext{
${ }^{4}$ More specifically, God creates humans in such a way as to be recipients God's love, which is Godself. Rahner makes it clear that the human person has no right to this gift, that it is pure grace, a gift from God, and thus "supernatural." This grace is freely offered to all. This is a concrete foundation of each person's existence (thus "existential"). See Declan Marmion, A Spirituality of Everyday Faith: A Theological Investigation of the Notion of Spirituality in Karl Rahner, Louvain Theological and Pastoral Monographs \#23 (Louvain, Belgium: Peeters Press, WB Eerdmans, 1998), 171-172.

${ }^{5}$ Harvey D. Egan, SJ, "Introduction" in Karl Rahner, The Need and Blessing of Prayer, trans. Bruce W. Gillette (Collegeville, MN: The Liturgical Press, 1997; originally published by Verlag Herder GmbH \& Co. KG. as Von der Not und dem Segen des Gebetes), xi.

${ }^{6}$ Karl Rahner, "Reflections on the Experience of Grace," Theological Investigations III, trans. Karl H. and Boniface Kruger, OFM (Baltimore, MD: Helicon Press, 1967; originally published by Einsiedeln, Benziger in 1956 as Zur Theologie des geistlichen Lebens), 87-88.
} 
God is experienced, albeit often unknowingly, in ordinary life. Rahner believes that the easiest "place" to notice this is in the depth or liminal experiences, where human beings are confronted with their own limitations, finitude or strength. Thus, for Rahner, the first way that humans experience God is simply through the mystery of who they are. "In Rahner's view, everyone is conscious of God, not as the 'predicamental' object of one's consciousness, but as the 'transcendental horizon' of consciousness itself. This 'implicit,' 'unthematic' form of Godconsciousness - an actual mystical consciousness - forms the ambience, the undertow, or the basal spiritual metabolism, of daily life."7

It is impossible to talk of the human person outside the context of this core identity. This also accounts for the restlessness of spirit experienced by so many: "The God-experience is the cause of our dissatisfaction with life, for nothing measures up to that which rests at our deepest center. The immense longing speaks to us, even if at times only in a whisper: this or that finite thing is ultimately not where we have set our hearts." ${ }^{8}$ Thus, the experience of God often exists as the experience of knowing something is wrong, or that there is a standard against which evil can be judged: "Where do atheists and agnostics acquire their often acute sensitivity to injustice, evil, suffering, and death if not from an even deeper experience of ultimate life, fulfillment, and meaning? In short, what provides the grounding for a radical experience of 'what ought not to be' for those who deny ultimate meaning a priori?"9 This type of experience is foundational, perhaps "utterly inescapable." ${ }^{10}$ Rahner attributes this unavoidable nature of the experience of God to the identity of human beings as transcendent.

This basic orientation to transcendence means that we are already, and always, open to the experience of Godself through grace, which is God's self-communication. Rahner speaks of a mysticism of everyday life, a recognition that the way to a more explicit faith for Christians is through the often boring or monotonous daily grind of life. We find God, not only in profound encounters, but also in the ordinary aspects of life. "The simple and honestly accepted everyday life contains in itself the eternal and the silent mystery, which we call God and his secret grace, especially when this life remains the everyday... Wherever people are, there they are creatures who unlock the hidden depths of reality in their free, responsible actions." "11 Because of who the human person is, these encounters with the often-difficult reality of life are also experiences of God, and one purpose of religion is to help people recognize more explicitly these experiences. "To Rahner, the prayer of everyday life exists not only as the immense longing, or even only as the undertow, vector, or implicit call to holiness found in every person's deepest interior. It becomes more explicit in the many good and lovely experiences that punctuate even the most

\footnotetext{
${ }^{7}$ Harvey D. Egan, Soundings in the Christian Mystical Tradition (Collegeville, MN: Liturgical Press, 2010), 339.

${ }^{8}$ Harvey D. Egan, Karl Rahner: Mystic of Everyday Life (New York, NY: Crossroad Publishing, 1998), 60-61.

${ }^{9}$ Egan, Karl Rahner, 67.

${ }^{10}$ Declan Marmion, A Spirituality of Everyday Faith: A Theological Investigation of the Notion of Spirituality in Karl Rahner, Louvain Theological and Pastoral Monographs \#23 (Louvain, Belgium: Peeters Press, WB Eerdmans, 1998), 116.

${ }^{11}$ Karl Rahner, The Mystical Way in Everyday Life: Sermons, Prayers and Essays, trans. and ed. Annemarie S. Kidder (Maryknoll, NY: Orbis Books, 2010), 173.
} 
banal lives." ${ }^{\prime 2}$ Rahner writes about walking, sleeping, sitting down, working, eating, and even about laughter. ${ }^{13}$ His comments range from reflections to searing questions. When writing about sitting down he says, "Do we have the courage, the discipline, and the freedom of heart to be quiet, to sit down? Do we become immediately bored when we have to sit down quietly and, while driving or travelling, throw ourselves into constant activity because we cannot endure ourselves, the quiet and the silence? Do we always have to be on the run because we are running away from ourselves?" "In speaking of the ordinary nature of the experience of God, Rahner is attempting to make the implicit explicit and help people to grow into a stronger and more firmly based Christian faith. In the words of Harvey Egan:

Rahner's theology of the mysticism of everyday life challenges everyone to look more closely at what is actually going on in the depths of their daily lives. What is implicit, hidden, anonymous, repressed, or bursting forth from the center of all we do? To Rahner, there is nothing profane about the depths of ordinary life. Whenever there is a radical self-surrender, an absolute yielding of everything, a surrender to the mystery that embraces all life - there is the Spirit of the crucified and risen Christ, the mysticism of everyday life. ${ }^{15}$

In stressing the ordinary nature of experiential knowledge of Holy Mystery, Rahner rejects "what he calls an élitist interpretation of Christianity. In his reflections on spirituality and mysticism, he insists that everyone is called to the immediacy of God's self-presence, a call which, of course, can be rejected. Underlying this assertion is God's universal salvific will, and radical self-communication to all." 16 This universality of the offer of salvation is key for Rahner. "In Rahner's view, every Christian is called to a mysticism of everyday faith, hope and love that differs only in degree, and not in kind, from the extraordinary experiences of recognized mystics." 17 In fact, for Rahner, this is an offer for all people, not just Christians, because all, by virtue of being human, are open to and actually are experiencing the transcendent.

Another way to approach this "ordinary" nature of the experience of God is through Rahner's prayers. Through his prayers we see a God that Rahner struggles with in the everyday. He wrestles with his attempts to understand this God, and to understand his own experience. They are, in a very real sense, "an attempt on Rahner's part to highlight and facilitate in his readers that encounter (Begegnung) with God, which, in his view, lies at the heart of prayer and spirituality." 18

Thanks to your mercy, O Infinite God, I know something about You not only through concepts and words, but through experience. I have met You in joy and suffering. For

\footnotetext{
${ }^{12}$ Egan, "Introduction," in The Need and the Blessing of Prayer, xiii.

${ }^{13}$ See The Mystical Way in Everyday Life for selections entitled "A Little Song," "About Seeing and Hearing," "About Work," “About Walking," “About Sitting Down," “About Seeing," "About Eating," "About Laughter,” and "About Sleeping."

${ }^{14}$ Rahner, The Mystical Way in Everyday Life, 177-178.

${ }^{15}$ Egan, Karl Rahner, 76-77.

${ }^{16}$ Marmion, A Spirituality of Everyday Faith, 61-62.

17 Ibid. 62.

${ }^{18}$ Ibid., 51.
} 
You are the first and last experience of my life. Yes, really You Yourself, not just a concept of You, not just the name which we ourselves have given You! ${ }^{19}$

This God to whom he speaks is met in joy and suffering, the ordinary facets of life. This is the same Mystery he encounters in eating and sleeping and walking. Yet he also lets his prayer lead him more directly into transcendence, where he faces the experience of relinquishing control and the experience of powerlessness implicit in being a creature:

Without You, I should founder helplessly in my own dull and groping narrowness. I could never feel the pain of longing, nor even deliberately resign myself to being content with this world, had not my mind again and again soared out over its own limitations into the hushed reaches which are filled by You alone, the Silent Infinite. Where should I flee before You, when all my yearning for the unbounded, even my bold trust in my littleness, is really a confession of You? ${ }^{20}$

As passionately as he speaks of the experience of God as a positive presence, he also struggles intensely with God's silence and seeming absence.

Why are You so silent? Why do You enjoin me to speak with You, when You don't pay any attention to me? Isn't Your silence a sure sign that You're not listening? Or do You really listen quite attentively, do You perhaps listen my whole life long, until I have told you everything, until I have spoken out my entire self to You? Do You remain silent precisely because You are waiting until I am really finished, so that You can then speak Your word to me, the word of Your eternity? Are You silent so that You can one day bring to a close the life-long monologue of a poor human being, burdened by the darkness of this world, by speaking the luminous word of eternal life, in which You will express Your very Self in the depths of my heart? ${ }^{21}$

With these prayers, Rahner lets his readers see his own struggles and in this process invites them to an encounter with Infinite Mystery. He does not promise understanding but rather an engagement that is both incomprehensible and intimate. "Prayer, to Rahner, is the last moment of speech before the silence; the act of self-surrender just before the incomprehensible God disposes of one; the reflection immediately proceeding the act of letting oneself fall - after the last of one's own efforts - and full of trust - into the infinite fullness and silence that reflection can never grasp." 22

From this exposition of Rahner's prayers, it is clear that Rahner considers prayer as an important part of the encounter with the Infinite. Through prayer he seeks to move past the basic spiritual experience that is revealed through everyday life. He believed that "prayer is best grasped by its practice [and this] means that when a person accepts him or herself in the totality of their existence and so experiences him or herself as confronted with the incomprehensible mystery embracing this existence, then such a person is living out what prayer really is and

\footnotetext{
${ }^{19}$ Karl Rahner, Prayers for a Lifetime, ed. Albert Raffelt (New York, NY: Crossroad Publishing, 1984; originally published by Verlag Herder Freiburg im Breisgau in 1984 as Gebete des Lebens), 17.

${ }^{20}$ Rahner, Prayers for a Lifetime, 11.

${ }^{21}$ Karl Rahner, Encounters with Silence, trans. James M. Demske, SJ (South Bend, IN: St. Augustine's Press, 1999; originally published by Verlag Felizian Rauch, Innsbruck, Austria in 1938 as Worte ins Schweigen), 20-21.

${ }^{22}$ Egan, Introduction to Rahner, The Need and the Blessing of Prayer, ix.
} 
means. Prayer, then is the event of the experience of God himself." ${ }^{23}$ Furthermore, prayer is the mechanism by which the human person actively appropriates the gift of grace and opens oneself to the transcendent.

It is important to note that Rahner was not, however, interested in trying to evoke an experience of religious enthusiasm such as is seen in the Catholic charismatic movement, though he did not condemn such experiences, which he called "mysticism in ordinary dress" or "mysticism of the masses." 24 This type of spiritual enthusiasm focuses on the external signs and the overwhelming experience. "For Rahner, to assume that the experience of the Spirit is limited solely to particular, isolated, special occasions is to adopt a fundamentally mythological understanding of the relationship of God to the world." ${ }^{25}$ Rahner, when possible, worked to demythologize the Christian faith. This idea of "magical" or "extraordinary" phenomena was one of his main concerns about so-called charismatic experiences, which could be cautiously accepted after having been tested for authenticity. Rahner did not deny the reality of this type of experience, but he was more interested in a calmer, more "sober" experience of the Spirit: "There is a mysticism of daily living, the finding of God in all things, the sober drunkenness of the Spirit mentioned by the Fathers of the Church and ancient liturgy, which we dare not reject or disdain just because it is sober." 26

Clearly, Rahner spoke about a deeper experience of God than people recognize in their everyday actions and that is different from the enthusiasm of the charismatic. He recognized and honored the experiences of the great saints and mystics, but did not see visions and extreme psychic phenomena as the sole or even suggested pathway for ordinary Christians. What then was the alternative? As a Jesuit, Rahner was firmly rooted in the Spiritual Exercises of St. Ignatius. He spoke and wrote of a mysticism that was a result of prayer and study that taught the believer how to find God in all things. This is an experiential knowledge of God, but it is not the ecstasy of the saints, nor the humdrum of everyday. Perhaps the clearest explanation of this type of experience is given to us by Rahner when he speaks as though he were Ignatius speaking to Jesuits today:

I encountered God; I experienced God's self. Even then, I could already distinguish between God's self and the words, the images, the particular limited experiences that somehow point to God... Godself I experienced - not human words about God. God, and the sovereign freedom that is proper to God, the freedom that can only be experienced as coming from God, not from the intersection of earthly realities... That's what it was, I say. Indeed, I would say this: you can have the same experience too, if you allow your skepticism - driven as it is by an underlying atheism - about such a claim to reach its limit, not just in eloquently expressed theory but also in actual bitter experience. For then something happens. ${ }^{27}$

\footnotetext{
${ }^{23}$ Marmion, A Spirituality of Everyday Faith, 73.

${ }^{24}$ Karl Rahner, "Religious Enthusiasm and the Experience of Grace," in TI XVI as quoted in Egan, Karl Rahner, 70.

${ }^{25}$ Marmion, A Spirituality of Everyday Faith, 148.

${ }^{26}$ Paul Imhof and Hubert Biallowons, eds., Karl Rahner in Dialogue: Conversations and Interviews, 1965-1982, trans. Harvey D. Egan (New York, NY: Crossroad Publishing, 1986), 297.

${ }^{27}$ Karl Rahner, "Ignatius of Loyola Speaks to a Modern Jesuit" as quoted in Spiritual Writings, ed. Philip Endean, Modern Spiritual Masters Series (Maryknoll, NY: Orbis Books, 2004), 38.
} 
An openness to this type of encounter with God involves active work for a person. In order to open oneself to the grace or free offer of God's self-communication, a person must choose to open her/himself to Ultimate Mystery. This happens in prayer, contemplation, and in often-difficult conscious choices. Rahner saw the direct encounter with the divine as crucial for Christians today:

For me in my theology the givenness of a genuine, original experience of God and his Spirit is of fundamental importance. This precedes logically (and not necessarily temporally) theological reflection and verbalization and is never adequately overtaken by this reflection. What Christian faith teaches is never communicated merely by a conceptual indoctrination from without, but is and can basically be experienced through the supernatural grace of God as a reality in us... an awakening, a mystagogy into this original, grace-filled religious experience is today of fundamental importance. ${ }^{28}$

This type of encounter with God requires great courage. For Rahner, a true and committed faith was not an easy thing. This is particularly true in modern times when Christian faith is not a real, intrinsic part of the culture:

In such a situation the lonely responsibility of the individual in his or her decision of faith is necessary and required in a way much more radical than it was in former times. That is why the modern spirituality of the Christian involves courage for solitary decision contrary to public opinion, the lonely courage analogous to that of the martyrs of the first century of Christianity, the courage for a spiritual decision of faith...Such a solitary courage, however, can exist only if it lives out of a wholly personal experience of God and his Spirit. ${ }^{29}$

This claim of a genuine, perceivable experience of God is urgently needed in the world today, given the hunger for spirituality or experience in general, and the ongoing abandonment of formal religion. Rahner's own assertion that the Christian of the future will be a mystic or will not exist gives us the greatest reason for urgency. ${ }^{30}$

\section{Applications for Spirituality Today}

Rahner has a great deal to offer contemporary spirituality, which is currently quite a challenging mix of disparate practices and ideas, encompassing everything from traditional practices like lectio divina and contemplative prayer, to practices inspired by native or Eastern religions. Perhaps it would be helpful to begin with defining spirituality, since there is quite a discrepancy in the various understandings of this word. Perhaps the most basic definition is "how one lives one's life in light of one's ultimate values." ${ }^{31}$ This understanding is too broad for our purposes, as is Hans Urs von Balthasar's definition: "that basic practical or existential attitude

\footnotetext{
${ }^{28}$ Rahner, Dialogue, 328.

${ }^{29}$ Karl Rahner, The Practice of Faith: A Handbook of Contemporary Spirituality, eds. Karl Lehmann and Albert Raffelt (New York, NY: Crossroad Publishing, 1986), 21-22.

${ }^{30}$ See footnote 4 above for full quote and reference.

${ }^{31} \mathrm{I}$ am indebted to Louis Savary, Ph.D. for this definition.
} 
(Grundhaltung) of a person which is the consequence and expression of the way in which they understand and live their religious - or more generally, their ethically committed - existence."32 We need a working definition of a specifically Christian spirituality. Sandra Schneiders offers a detailed definition:

The particularity of Christian revelation is constituted by the specificity of revelation focused in the incarnation and resurrection of Jesus Christ, the revelation of the transformation through death of humanity into God. This is the foundation of the sacramental intuition, the reading of all creation which is the unique Christian "take" on the real relation of Transcendence to immanence, the mediation not only of transcendence but of the Transcendent in human being, human experience, human particularity, human history, human destiny. Christian spirituality is the experience of living that reality. . . 33

In short, a definition of Christian spirituality might be: the reality of living the experience of being radically oriented toward Ultimate Mystery within the Christian context (i.e., through Christ, in the Spirit).

This definition elucidates the first thing that Rahner has to offer contemporary spirituality: an understanding of the human person that is flexible and open to the possibility of growth and development. This type of anthropology is something desperately needed by contemporary society, which is suffering from a lack of engagement with philosophy and theology. Old philosophical definitions of the human person from ancient Greek philosophy are no longer being studied as a regular part of school curricula. It could be argued that this is due to a lack of perceived relevance today. Instead, ideas about who the human person is come from the physical sciences, such as biology and chemistry, and the social sciences, particularly sociology and psychology. This is supplemented by mass media caricatures and illusions. Contemporary society needs a common understanding of the human person that is positive, growth-oriented, and flexible, without being in conflict with either science or scripture. Rahner offers this type of understanding.

In addition to the lack of common consensus on the human person, there is also much that is problematic in Christian spiritual practice, particularly among Catholics. At present, there is an unhelpful distinction between theology and spirituality. Within the academy, theology is often perceived as a strictly academic pursuit, and, as such, is seen as divorced from "messy" experience or popular piety. The practice of faith and the articulation of theology are often approached as totally separate. Instead, theology has gained a reputation for being too intellectual and inaccessible and separate from practice or practicality, particularly among nonacademics. "Rahner resolutely refused to divorce theology and spirituality into separate disciplines because of his conviction that one cannot exist without the other." 34 For Rahner: "All

\footnotetext{
${ }^{32}$ Hans Urs Von Balthasar, "The Gospel as Norm and Test of all Spirituality in the Church" as quoted in Marmion, A Spirituality of Everyday Faith, 18.

${ }^{33}$ Sandra M. Schneiders, "Spirituality and the God Question" in Spiritus: A Journal of Christian Spirituality, Vol 10, No 2, Fall 2010, 249. Note that this definition seems to incorporate some of Rahner's thinking.

${ }^{34}$ Harvey D. Egan, "Theology and Spirituality" in The Cambridge Companion to Karl Rahner, eds. Declan Marmion and Mary E. Hines (Cambridge, UK: Cambridge University Press, 2005, 2007), 14.
} 
theological reflection, all theological statements, have their root in the holy mystery of God."35 Because of this refusal to separate theology from experience, Rahner's writing gifts his readers with an understanding of an "...experiential union with this faith by leading them into their own deepest mystery." 36 So strong is this conviction that he identifies this split as "the horrible difference which is often to be observed in later theology, between theology and spiritual life."37 This is something that needs to be more deeply explored. The wealth of Christian tradition is not being made accessible to the average "person in the pews." Rahner ${ }^{38}$ brings the rich, experiential tradition into modern terms and accessibility. He draws on the spirituality of St. Ignatius of Loyola for his grounding in this area. What Rahner offers is a broad based theological foundation for his experiential claims. He engages spirituality with the same academic rigor and depth that he uses for more traditional academic topics.

This is particularly important because there is much that passes for spirituality today that is not grounded in theology or other academic disciplines. All that is needed to become a spiritual teacher is a creative idea and a persuasive personality. While there has been a decline in active participation in formal religion in recent years, there has been an upsurge in interest in spirituality. This can be seen in the large number of books and seminars dedicated to spiritual practices, particularly in the category known as "new age," and an increase in the number of people eschewing formal religion and claiming to be "spiritual" but not "religious." This trend may be interpreted as an expression of frustration with doctrines, dogma, and rules, as well as a corresponding desire for experience. People are hungry for something more, and those who are not finding sustenance and help in their religious tradition or practice are often willing to try new things. Many practices that have deep roots in non-Christian religious traditions are being separated from the discipline of their original contexts and presented as worthwhile spiritual practices in isolation. The marketplace is filled with chakra meditations, crystals, shamanic journeys, Kabbalah for non-Jews, and many other things that lead searching people from one "experience" to the next, without any real grounding in tradition or life.

Rahner offers a complex and remarkably complete theology, which is both a result of prayer and experience of God, and a possible entrance for the serious student into this encounter with Mystery. His material will challenge the most intellectual of thinkers, while offering a more direct experiential entrée through his spiritual writings. This is a new understanding of an experiential Christianity that starts from Rahner's anthropology, meaning that it begins with how he understands human identity. He reclaims the concept of personal relationship within a context of Christian sacramental community for Catholics. As such, Rahner can be called a mystagogical theologian, or one who draws his readers into their own encounters with Mystery. ${ }^{39}$ This is a melding of "orthodoxy" with experience that would meet the needs of many people if it were made more accessible. As Rahner himself says:

\footnotetext{
${ }^{35}$ Marmion, A Spirituality of Everyday Faith, xli.

${ }^{36}$ Egan, "Theology and Spirituality," 15.

${ }^{37}$ Karl Rahner, "Thomas von Aquin" as quoted in Marmion, A Spirituality of Everyday Faith, 43.

${ }^{38}$ And others, such as Teilhard de Chardin, Anthony DeMello, and Margaret Silf.

${ }^{39}$ Egan, "Theology and Spirituality," 15.
} 
I am convinced that such an immediacy between God and the human person... is of greater significance today than ever before. All the societal supports of religion are collapsing and dying out in this secularized and pluralistic society. If, nonetheless, there is to be real Christian spirituality, it cannot be kept alive and healthy by external helps, not even those which the Church offers, even of a sacramental kind...but only through an ultimate, immediate encounter of the individual with God. ${ }^{40}$

This conviction is based on the fact that the "starting point" of Rahner's theology and spirituality is his "own personal experience of God (with its insights as well as its questions). From this concrete starting-point, he attempts to understand the traditional faith of the Church. He also invites others to discover similar experiences in themselves, or even to consider theologizing from quite different experiences." ${ }^{.11}$

Sadly, contemporary Catholic faith and practice lacks understanding of the offer of God's direct self-communication to humanity. Many active Catholics are unaware that an experiential encounter with God is part of their rich tradition. Instead, their focus is on the mediation of God through sacrament and scripture. Rahner offers an option that is firmly rooted in these traditions of word and sacrament, while stressing, and even evoking, an experience of Ultimate Mystery. This type of experiential knowing is desperately needed in the church today in order to give people a more robust faith and a deeply spiritual practice. As modern communication makes the world smaller and people from distant countries become "neighbors," Christians need a faith that will help them to expand hearts and minds. "Every authentic religious epiphany or encounter, every true experience of God in whatever form, makes a person less insular, less complacent, and less isolated - and more restless, more inspired and more engaged with the world and humanity." ${ }^{, 42}$ This makes the need for a genuine experience of God quite urgent for people today. Rahner offers a way to this encounter that is not shrouded in mystical (or magical) language, and is not outside the ability of the ordinary person.

There is a very practical and concrete purpose in Rahner's desire to bring people to a recognition of their own encounter with Mystery. "...The aim of Rahner's approach is to bring the person to a decision or choice which embraces the whole of one's existence, and which will lead to the radical re-ordering of one's transcendental nature towards the immediate reality of God. ${ }^{43}$ In other words, Rahner's approach is oriented towards encouraging a person to make a fundamental option for God. This has obvious applications today when faith and religious commitment are choices within a large field of options.

\footnotetext{
${ }^{40}$ Rahner, Dialogue, 176.

${ }^{41}$ Marmion, A Spirituality of Everyday Faith, 69-70.

${ }^{42}$ Anthony J. Gittins, A Presence that Disturbs: A Call to Radical Discipleship (Liguori, MO: Liguori/Triumph, 2002), 12.

${ }^{43}$ Marmion, A Spirituality of Everyday Faith, 150.
} 


\section{Rahner's Contributions to Feminist Theology and Spirituality}

In addition to the gifts he offers to general spiritual practice, Rahner offers some particular resources for feminist theology and spirituality, some of which have already been incorporated. Many feminists have adopted his language and way of speaking about God as a starting place for new speech about the Holy. Terms like Mystery are non-gendered and thus very welcome as alternates to male terminology and pronouns for God. In expanding language about God in this way, Rahner opens the way for theologians like Mary Daly, Elizabeth Schüssler Fiorenza, and Rosemary Radford Ruether to explore the implications of using gendered language for God. Elizabeth Johnson has enhanced the discussion by building on this foundation to develop the theological grounding for feminine language for God in She Who Is. She relies on the rich tradition of the incomprehensibility of God, which was reasserted by Rahner in contrast to a framework that had become too formulaic. Unfortunately, he is often criticized for the language that puts an emphasis on transcendence and ignores immanence. This is unfair and an incomplete understanding since his focus on experience is all about a personal encounter and relationship, while maintaining the absolute "otherness" of Mystery.

Catherine Mowry LaCugna sees Rahner as foundational for reintroducing "interest in trinitarian theology." 44 She builds on this interest, as well as Rahner's assertion that the economic Trinity is the immanent Trinity and vice versa, as well as his understanding of grace as God's Self-communication, to develop her Trinitarian theology. Nancy Pineda-Madrid acknowledges her indebtedness to Rahner, and others, in the area of salvation involving engagement with the world. This is the foundation on which she builds her "reimagination of salvation." 45

Despite Rahner's significant influence on feminist theology, there is one area that has received less attention by feminists than it deserves. This is his overall emphasis on the experience of God. While feminist theology begins from the experience of women, it often focuses primarily, or sometimes exclusively, on the concrete daily experiences of women, and their ways of naming and understanding the divine. Many feminist writers shy away from talking about direct encounters with a personal God. There are several excellent reasons why this may be the case. The first is that the maleness of Jesus has been used in particularly problematic and totally unnecessary ways to denigrate women. Examples include using the maleness of Jesus to assert that women cannot image Christ, using the maleness of Jesus to insist on male leadership in church and society, using the fact that the male Jesus used the male term Abba (Father or "Daddy") for God to make the male experience normative and to insist on the dominance of the male in the family and in society. A second possible reason for the relative silence on this issue is association of emotion or feeling with the "feminine," which is contrasted with the rational or unemotional masculine. Experiences that involve intuition, emotion, or anything else that is not

\footnotetext{
44 Catherine Mowry LaCugna, God for Us: The Trinity and Christian Life (New York, NY: HarperCollins Publishers, 1993, original publication date 1992), 210.

${ }^{45}$ Nancy Pineda-Madrid, Suffering and Salvation in Ciudad Juárez (Minneapolis, MN: Fortress Press, 2011 ), 1.
} 
measurable by scientific means, become problematic and cannot be addressed by women lest their seriousness or scholarly credentials be doubted. Anything that can add to gendered stereotyping is potentially a problem.

Cautiously appropriated, Rahner's theology provides a corrective in both of these areas. A major theme of Rahner's experiential theology is the encounter with Mystery as mystery. It is not that Rahner has no emphasis on Jesus, but that one need not start with Jesus to look for God, since the experience of transcendence is part of being human. Encounter with the risen Christ in prayer takes us to a new level but it does not start the experience. While maintaining the central significance of Jesus, Rahner does not emphasize his maleness. This means that we can retrieve his experiential focus without needing to fear this area. In fact, though many feminists have now moved away from Christology as such, Elizabeth Johnson has found rich resources in Rahner:

Karl Rahner has envisioned that because of the Word of God in our midst, it can now be seen that each of us is a little word of God. The one Word of God uttered in our midst reveals to us our own beauty, for we are each a little word and together we will spell out something great. Again, he describes each of us as a letter of the alphabet; when we are all assembled we will spell out a great word to the glory of God: "Human nature is the grammar of God's self-utterance." Our human nature is so made that God can speak in and through us. All of this flows out of the incarnation, which is real and not a pretense on God's part. That God actually became one of us leads us to value all human beings as gifted with a tremendous dignity precisely as human. ${ }^{46}$

For Rahner, the experiential encounter is always directly with God, who is not male, female or any other category we might design. This means that his experiential focus has great potential for feminist theology and spiritual practice. One example is the need for women to regain and claim their true selves. Johnson uses Rahner's theology to stress this point: "Personal development of the self also constitutes the development of the experience of God; loss of self-identity is also a loss of the experience of God... Consequently, when a person claims the self in freedom... or affirms oneself in trustful acceptance, then the changing history of this self-revelation also entails living through a changing history of the experience of God." ${ }^{, 47}$ The theology of Rahner feeds this dynamic envisioning of the process of human growth into full personhood.

In She Who Is, Johnson draws on Rahner in her work of reclaiming the basis of Trinitarian language in the experience of God:

For this language is not a literal description of the inner being of God who is in any event beyond human understanding. It is a pointer to holy mystery in trust that God really is the compassionate, liberating God encountered through Jesus in the Spirit. It is language which affirms that what is experienced in Christian faith really is of God; that what we are involved with is nothing other than saving divine mystery. At rock bottom it is the language of hope. ${ }^{48}$

\footnotetext{
${ }^{46}$ Elizabeth A. Johnson, Consider Jesus: Waves of Renewal in Christology (New York, NY: Crossroad, 1990), 33.

${ }^{47}$ Elizabeth A. Johnson, She Who Is: The Mystery of God in Feminist Theological Discourse (New York, NY: Crossroad, 2009), 65-66.

${ }^{48}$ Johnson, She Who Is, 200.
} 
This reclaiming of the experience of God at the root of doctrine gives feminist theology a vibrancy that comes from the integration of theology and spirituality. This energy has much to offer the larger church and there is more work to be done in reintegrating the ongoing, and not simply historical, encounter with God into the daily lives of believers.

\section{Implications for the Church Today}

Rahner's emphasis on the encounter with Mystery should make Rahner's theology vibrant and alive for ordinary Christians, but this has not been the case. Paradoxically, one of the primary factors in the relative inaccessibility of Rahner to ordinary Catholics is the fact that we have moved farther from his ideal envisioning of Church rather than closer. He dreamed of a church where the local community has far more influence and importance; where the focus is on love and community. He also saw the possibility for a church where power is shared and Christian unity might be a real possibility. ${ }^{49}$ This type of community is much more able to be open to experiential encounter, because it is less encased in rigid structures, and less afraid of innovation, questions, and change.

While this envisioning of a different understanding of power is a gift to the Church all by itself, the local church he envisions is very important. Each member will take ownership of her/his faith: "The Church at the level of the local community will be the community of those who freely believe, of those who have taken their own personal decision." $50 \mathrm{He}$ sees a Church centered around love and the personal relationship with Ultimate Mystery. This church requires the kind of experience of God around which Rahner's theology is focused. This is a powerful vision:

The community of the new Church must be a community of love, and love is extremely practical. But it is better for us to admit to ourselves in all honesty that as yet we hardly know what outward shape a community living by practical love in this way can assume. We are only capable of obtaining something when we do not believe that we already possess it, and this applies here also. ${ }^{51}$

Unfortunately, this is not the direction the Church has taken in recent years. In Gaudium et Spes, the Second Vatican Council settled on an understanding of the church as the people of God, replacing "the juridical, hierarchical definition of church with more biblical and symbolic images and clearly articulated a sense of the church as taking its form and function from its relationship to the kingdom of God." ${ }^{, 52}$ In the years since the Council, there have been several moves to

\footnotetext{
${ }^{49}$ See Karl Rahner, "Dream of the Church," Theological Investigations XX, trans. Edward Quinn, ed. Paul Imhof, SJ (New York: Crossroad, 1981; originally published by Einsiedeln, Benziger, 1980 as In Sorge um die Kirche), 133142.

${ }^{50}$ Karl Rahner, "The New Image of the Church," Theological Investigations X, trans. David Bourke (New York, NY: Seabury Press, 1977; originally published by Einsiedeln, Benziger in 1967 as Theologische Vorträge und Abhandlungen), p. 25.

${ }^{51}$ Rahner, "The New Image of the Church," 26-27.

52 Catholic Social Thought: The Documentary Heritage, eds. David J. O’Brien and Thomas A. Shannon (Maryknoll, NY: Orbis Books, 2010), 171.
} 
consolidate central, or papal power. ${ }^{53}$ The move away from a church of the people of God and toward a more magisterial understanding of church has worked against the incorporation of Rahner's theology as a resource for spiritual practice. The very thing that his theology could help counteract - a focus on doctrine to the exclusion of experience - renders his work inaccessible for many theologians and ordinary Christians. Perhaps this could be "countered" by a focus on the more spiritual writings for now, in the hope that a time of greater openness to the Spirit is coming. For that is really the issue here. Rahner's theology seeks an engagement of the Church with the Spirit of God, a fearless encounter in love. This kind of experience requires both courage and love. It has the potential to radically change Church structures and breathe new life into the traditions. The Church of the future, and the Christian of the future, will be different from what exists now. This kind of change can be frightening, but Rahner has great confidence in both humanity and in the Spirit of God. His spiritual writings provide a mystagogical introduction to the explicit experience of God, offering a firm foundation for a future integrated theology, and spirituality open to the gifts of the Spirit.

Ultimately, the question that Rahner asks us to consider is the question of Jesus: "Who do you say that I am?" Despite an impressive corpus of work, his answer is an unexpected invitation from Jesus: "Come and see." Rahner encourages us to enter the conversation. His desire is that people will speak of and take seriously the God they have encountered. His theology shies away from easy answers and either/or thinking. He asks us to let love cast out fear and to stay in the place of tension between experience and tradition, prophecy and obedience, presence and absence, and between new and old. He demands the integrity of both/and thinking - intellectual and spiritual, kataphatic and apophatic, creativity and obedience. He has great gifts for the church as we move into the future; if we will only find a way to embrace them as we accept the challenge of our questions and our doubts.

53 See, for example, the discussion of the Council in Edward Schillebeeckx, I am a Happy Theologian: Conversations with Francesco Strazzari, trans. John Bowden (New York, NY: Crossroad Publishing, 1994), 13-29. 